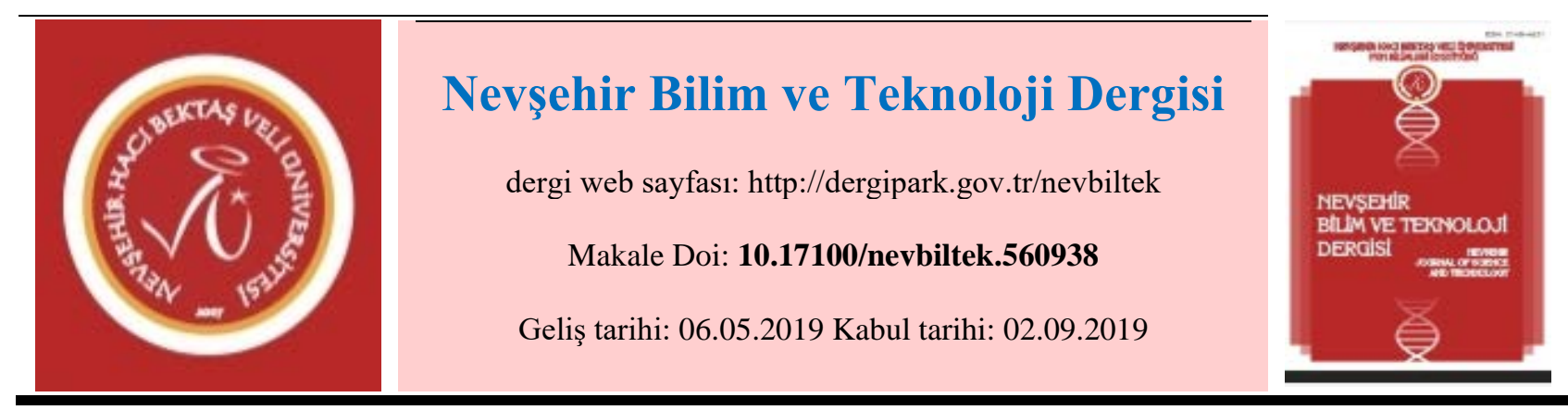

\title{
Planning of Tram Stop Design: Usak University Sample ${ }^{1}$
}

\author{
Julide ONER $^{1,}$, Ismet KARA ${ }^{2}$ \\ ${ }^{1}$ Usak University, Faculty of Engineering, Department of Civil Engineering, Usak \\ ORCID ID: 0000-0003-3229-152X \\ ${ }^{2}$ Usak University, Graduate School of Natural and Applied Sciences, Usak \\ ORCID ID: 0000-0002-3396-1428
}

\begin{abstract}
Considering today's conditions, people prefer to live in cities as a result of social, political, cultural and most importantly technological developments. Therefore, the population rate of cities is increasing day by day. Due to the traffic distress experienced in urban transportation, it becomes necessity to use the public transportation vehicles which are less harmful, more noise-free, more comfortable, faster and safer. The city of Usak is one of the cities that are constantly developing and growing as well as it is receiving immigration from the surrounding provinces. This increase results as raises traffic problems in Usak city. The aim of this paper is to determine the route of tram system, design of tram stops and evaluate solutions with the tram systems to the problems experienced in traffic between Usak city and Usak University campus. Besides, the general characteristics of route between Usak city and Usak University campus are mentioned and the necessity of the tram system design project for Usak has been emphasized
\end{abstract}

Keywords: Transportation, traffic problems, tram system, design, tram stop.

\section{Tramvay Durak Tasarımlarının Planlanması: Uşak Üniversitesi Örneği}

$\ddot{\mathbf{O z}}$

Günümüz koşulları göz önünde bulundurulduğunda sosyal, siyasal, kültürel ve en önemlisi teknolojik gelişmeler neticesinde insanlar kentlerde yaşamayı daha çok tercih etmektedir. Kent içi ulaşımda yaşanan trafik sıkıntıları sebebiyle kullanıcıların ihtiyaçları göz önünde bulundurularak tasarlanmış çevreye daha az zarar veren, daha gürültüsüz çalışan, konforu yüksek, daha hızlı ve daha güvenli toplu taşıma araçlarının kullanılmaș zorunlu hale gelmektedir. Uşak ili sürekli gelişen ve büyüyen, dışarıdan göç alan şehirlerden biridir. Bu artış beraberinde Uşak ilinde de trafik sorunlarını gündeme getirmekte ve trafik akışı zor hale gelmektedir. Bu çalışmanın amacı; tramvay sistemi güzergahını belirlemek, tramvay duraklarının tasarımını yapmak ve tramvay sistemleri ile Uşak şehri ve Uşak Üniversitesi kampüsü arasındaki trafikte yaşanan sorunlara yönelik çözümleri değerlendirmektir. Ayrıca, çalışma sonuçlarında Uşak şehri ile Uşak Üniversitesi kampüsü arasındaki yolun genel özelliklerinden bahsedilmekte ve Uşak tramvay sistemi projesinin gerekliliği vurgulanmaktadır.

Anahtar Kelimeler: Ulaştırma, trafik problemleri, tramvay sistemi, tasarım, tramvay durağı.

\footnotetext{
${ }^{1}$ A part of this study was presented at the 2nd International Congress on Engineering and Architecture (ENAR) Marmaris / Turkey, 22 - 24 April 2019.
}

Corresponding author e-mail: julide.oner@usak.edu.tr 
Nevşehir Bilim ve Teknoloji Dergisi (2019), 8(Enar Özel Sayı) 118-124

\section{Introduction}

The city of Usak is located on the Ankara-Izmir highway in the Aegean Region. Usak is a developed and developing city in terms of industry. Depending on this development, continuous external migration is taken. In addition, the number of students increases with the presence of Usak University in the city. Depending on all these conditions, the number of people living in the city is increasing every year. Traffic problems have occurred accordingly. In addition, buses that provide transportation within the city cannot meet the passenger demand at the desired level. All these problems are planned to be solved by tram system for Usak.

Rail systems are applied on the rail or hanging on the rail, with stations on the route [1]. These systems respond to passenger demands faster, more economically and more effectively. Rail public transportation systems consist of 4 main systems: trams, light rail systems, subways and suburban trains [2].

Trams run on rails, can use the same route as road traffic, electrical energy to operate, is usually used for close distances is a public transport system [3]. The system has a width between 2200-2650 mm. The length of the vehicles varies between $14-21 \mathrm{~m}$. The maximum length of the station is $60 \mathrm{~m}$. [4]. The maximum speed of the trams is $50 \mathrm{~km} / \mathrm{h}$ and the operating speeds are $30 \mathrm{~km} / \mathrm{h}$. [4].

Light rail systems are the state of the classic trolley, which is controlled by a driver and is controlled by passengers. Rail clearance is 1435 mm. Distance between stations varies between 600-1000 m. Maximum speeds are 80 $\mathrm{km} / \mathrm{h}$. The vehicle width is $2650 \mathrm{~mm}$. [5].

Metros can reach high speeds, full protection, with driver or driverless is a public transportation system that provides the transportation [6]. Ray openings are generally $1435 \mathrm{~mm}$., width is between 2650-3150 mm. Besides, station lengths are approximately $200 \mathrm{~m}$. [7].

Suburban trains are a public transportation system that has similarities with the subway system as well as the size of the vehicles and the distances between the stations are higher than other systems, serve at longer distances [8].

When all these rail public transportation systems were examined, it was decided to implement the tram system for the city of Usak. For the tram system, a route which is used by a city intensively is determined. The stations are placed on this route. The requirements of the Tram Design Criteria Manual published by the General Directorate of Infrastructure Investments in 2011 should be complied with in the design of the tramway project [8].

The route of the planned tram line has the same route with the Ankara-Izmir highway, which is used extensively by people living in Usak. Due to the presence of shops, dwellings, government offices, hospitals, universities etc. on this highway, traffic on the highway from the passengers in the city is also intense. With the tramway system, transportation to Usak will be easier, traffic accidents and traffic problems will be minimized and passengers will reach their destinations faster, safer and more comfortably. In addition, environmental and noise pollution will be prevented with the tram system [9]. As a result, the best way to meet passenger demands is through the tram system [10].

\section{Research Findings and Discussion}

The city of Usak is one of the cities that are constantly developing and growing as well as it is receiving immigration from the surrounding provinces. This increase results as raises traffic problems in Usak city. The aim of this paper is to determine the route of tram system, design of tram stops and evaluate solutions with the tram systems to the problems experienced in traffic between Usak city and Usak University campus.

The passengers living in the city of Usak should use the Ankara-Izmir road passing through the Usak office to provide transportation to Usak University, Usak Training and Research Hospital, Usak Airport and Usak Organized Industrial Zone. The designed tram line also has this route. 
The stations are planned at certain points according to the passenger demands on this route. Usak Tramway West Line ends at Dörtyol starting from Usak University. The red line of the tram line is shown in the Figure 1 below.

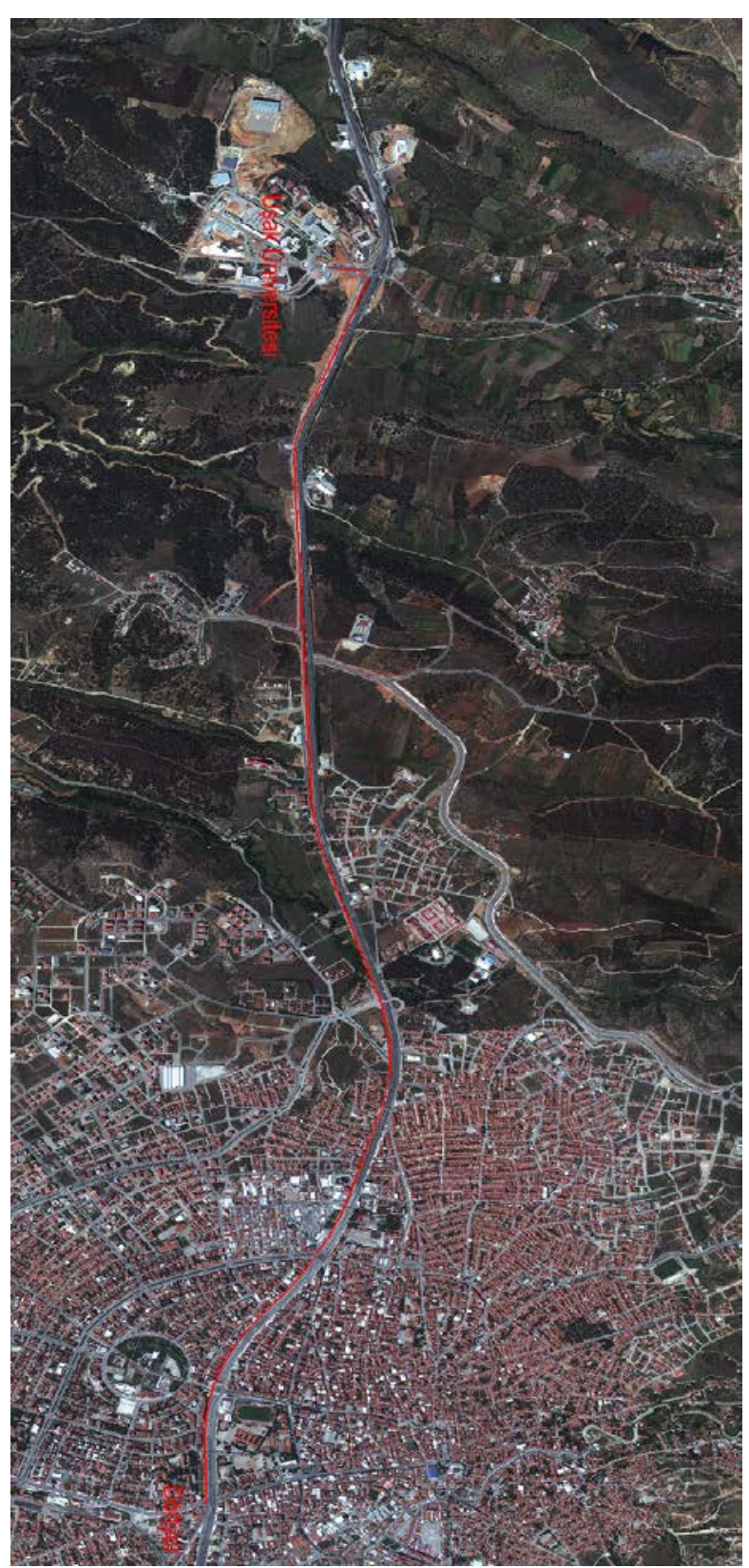

Figure 1. The route of west line (Dörtyol-Usak University line)

The Usak Tramway, which is indicated by a red line, starts at Usak University and ends at $6750 \mathrm{~m}$. So the total length of the west line is $6750 \mathrm{~m}$. Usak Tramway Western Line is illustrated in Figure 2 by use of Netcad Program Image.

There are a total of 9 stations on the West Line of Usak Tramway (Platform 1- Platform 9). In addition to these stations, one line maintenance office area with $7800 \mathrm{~m} 2$ was designed in Usak University area. Tram stations are listed in Table 1. The Autocad Image of Line and Maintenance Offices is shown in Figure 3.

It is thought that the platforms which will be used in the tram lines which are the most intensively used stations will be university (Platform1) and Dörtyol (Platform 9). Then it is expected that there will be a density at the Platform 7 and the Platform 8. In the light of this information, it is planned that the ticketstocks will be on Platform 1, Platform 7 , 
Nevşehir Bilim ve Teknoloji Dergisi (2019), 8(Enar Özel Say1) 118-124

Platform 8 and Platform 9. It is predicted that the western line of the tramway will carry 35000 passengers in 2 directions daily.

Table 1. Lists of tram stations at Western Line

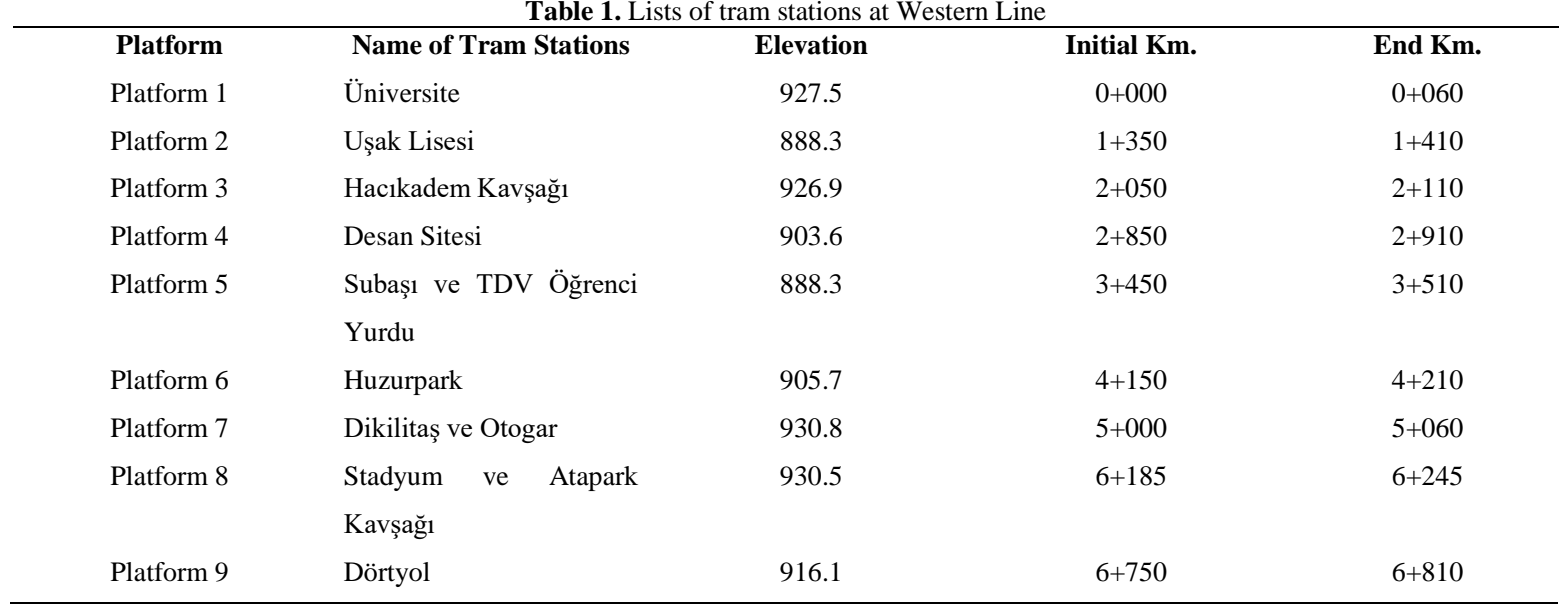
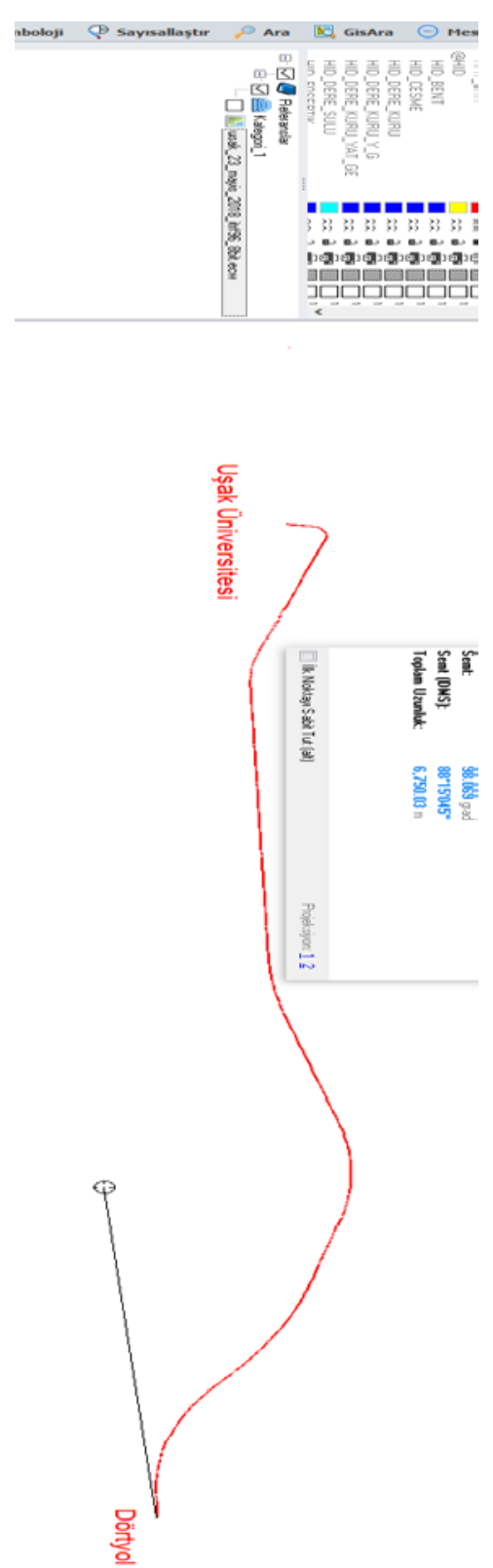

Figure 2. The route of west line (Dörtyol-Usak University line) is illustrated by Netcad Program 


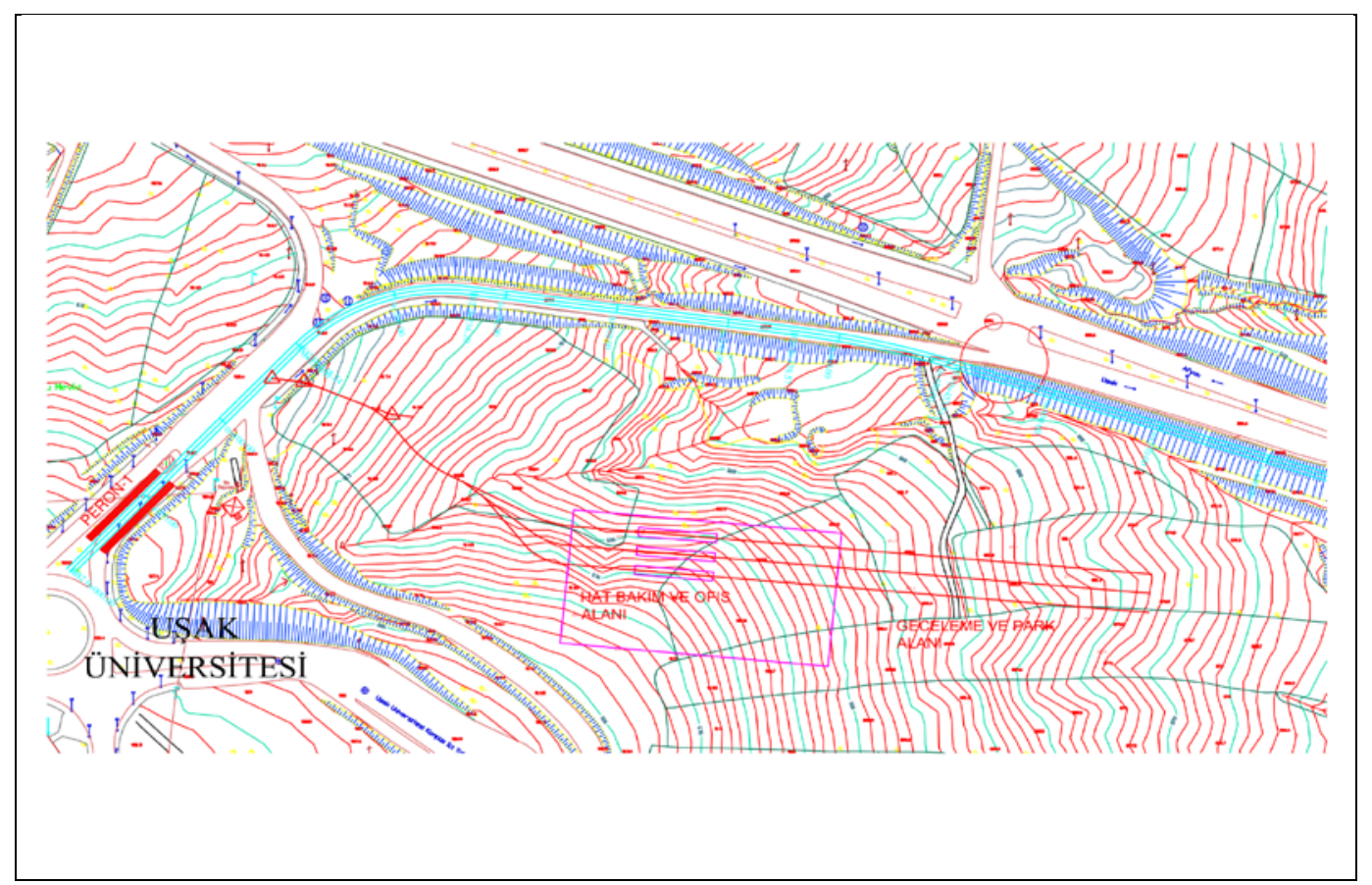

Figure 3. The Autocad Image of line and maintenance office

The project will be based on the Samsun Tramway, which was started to be constructed in 2016, while the cost is calculated. The reason for taking the base of Samsun Tram is that it is the most similar project in the nearest history. The total line length of Samsun Tram is $15.7 \mathrm{~km}$ and consists of 15 stations and 1 maintenance office. In addition to the tram line; 1 line maintenance and office area is planned for the route of west line (Dörtyol-Usak University line). The Samsun Tramway is expected to total cost 105 million Euros in 2016 [10]. So the cost of km related to the Samsun Tramway is 6.69 million Euros.

Hence, the total cost of Usak Tramway Western Line (Usak University-Dörtyol is estimated to be 281 million TL according to 2019 exchange rates. It is expected that 35,000 passengers will travel in 2 directions with the arrival of the tram. Assuming that Usak Tram passenger ticket costs 1.75 TL, 12.74 years may pay for itself.

\section{Results and Suggestions}

The traffic problems experienced due to the number of vehicles are increasing due to the population increase. City buses cannot give the required response to the passenger demand and the rail system applications are implemented accordingly.

The increase in the number of migrants and the number of students in Usak increased the population density. Accordingly, traffic problems have occurred and passenger demands have become difficult to meet. In order to find solutions for all these problems, tram project, which is one of the rail public transportation systems, has been considered and the design of the western line (Usak University-Dörtyol) has been designed.

For the route of the tram line, a route was used intensively by the city of Usak and the stations were placed on this route. It is foreseen that 3500 passengers will be transported in 2 way in the accounts made due to the existence of Usak University on the western line of the tram. According to the calculated number of passengers, the system is calculated to pay off at the end of 12.76 years.

As a result, it is an indication of the feasibility of the project to pay less than 15 years in such large projects around the world. As Usak Tramway Western Line has less than 15 years to pay, the project is financially feasible. 
[1] Pan, D., Zhao, L., Luo, Q., Zhang, C. and Chen, Z.,"Study on the performance improvement of urban rail transit system", Energy, 161, 1154-1171, 2018.

[2] Zyngier, D., Lategan, J. and Furstenberg, L., "A process systems approach for detailed rail planning and scheduling applications",Computers\&Chemical Engineering, 114, 273-280, 2018.

[3] Chen, C.L., "Tram development and urban transport integration in Chinese cities: A case study of Suzhou", Economics of Transportation, 15, 16-31, 2018.

[4] Cirit, F., "Sürdürülebilir Kentiçi Ulaşım Politikaları Ve Toplu Taşıma Sistemlerinin Karşılaştırılması", Republic of Turkey Ministry of Development Specialization Thesis, Turkey, 2014.

[5] Vuchic V., "Urban Transit : Operations, Planning and Economics", John Wiley\&Sons. Inc., Canada, 2005.

[6] Zhao, L., Wang, J., Gao, H.O., Xie, Y., Jiang, R., Hu, Q. and Sun, Y., "Evaluation of particulate matter concentration in Shanghai's metro system and strategy for improvement, Transportation Reseach Part D, 53 : 115-117, 2017.

[7] Baştürk, G., "Kent İçi Raylı Toplu Taşıma Sistemleri İncelemesi Ve Dünya Örnekleri İle Karşılaştırılması", Ministry of Transport, Maritime Affairs and Communications, Transport and Communication Expertise Thesis, Turkey, 2014.

[8] Kasımoğlu, E., "Tramvay Istasyonlarında Tasarım Ve Güvenlik Esaslarının Araştırılması İstanbul T1 Tramvay Hattı İncelenmesi", İstanbul Technical University, Applied Science Institute, MSc Thesis, Turkey, 2015.

[9] Delfa, S.L., Enjalbert, S., Polet, P. and Vanderhaegen, F., "Eco-driving command for tram-driver system", IFAC-Papers OnLine, 49, 444-449, 2016.

[10] Yıldırım, E., "Kentsel Raylı Sistemlerin Planlanması Bursa Örneği", Bahçeşehir University, Applied Science Institute, MSc Thesis, Turkey, 2013.

\section{Genişletilmiş Özet}

\section{Giriş}

Kentlerde artan nüfus beraberinde birçok sorun meydana getirmektedir. $\mathrm{Bu}$ sorunların en önemlisi nüfus artışına bağlı olarak çoğalan araç sayısı sebebiyle yaşanan trafik problemleridir. Gelişen şehirlerde şehir içi otobüsler yolcu talebine gerekli cevabı verememekte ve buna bağlı olarak raylı sistem uygulamaları hayata geçmektedir. Raylı sistemler ray üzerinde yada raya asılı bir biçimde uygulanan, güzergahı üzerinde istasyonları bulunan sistemlerdir. Bu sistemler yolcu taleplerine daha hızlı, daha ekonomik ve daha etkin bir şekilde cevap vermektedir. Raylı toplu taşıma sistemleri tramvaylar, hafif raylı sistemler, metrolar ve banliyö trenleri olmak üzere 4 ana sistemden oluşmaktadır. Tramvaylar raylar üzerinde hareket eden, karayolu trafiği ile aynı yolu kullanabilen, çalışmasını elektrik enerjisiyle gerçekleştiren, genellikle yakın mesafeler için kullanılan bir toplu taşıma sistemidir. Tramvay sisteminde araçlar 2200$2650 \mathrm{~mm}$ arası genişliklere sahiptir. Araçların uzunlukları ise 14-21 m arasında değişmektedir. Tramvay sistemlerinde yapılacak istasyon boyları maksimum $60 \mathrm{~m}$ olmalıdır. Tramvayların maksimum hızları $50 \mathrm{~km} / \mathrm{sa}$ olmakla beraber işletme hızları ise $30 \mathrm{~km} / \mathrm{saattir}$.

Raylı toplu taşıma sistemleri bir arada incelendiğinde Uşak ili için tramvay sisteminin uygulanmasına karar verilmiştir. Tramvay sistemi içi bir şehrin yoğun olarak kullandığı bir güzergah belirlenmiştir. Bu güzergah üzerine 
istasyonlar yerleştirilmiştir. Tramvay projesini tasarımında Altyapı Yatırımları Genel Müdürlüğü'nün 2011 yılında yayımladığı Tramvay Tasarım Kriterleri El Kitabı'nda yer alan şartlara uyulmuştur.

\section{Yöntem}

Uşak ili Ege Bölgesi'nde, Ankara-İzmir karayolu üzerinde bulunmaktadır. Uşak sanayi bakımından gelişmiş ve gelişmeye devam eden bir şehirdir. Bu gelişmeye bağlı olarak sürekli dış göç almaktadır. Ayrıca şehirde bulunan Uşak Üniversitesi'nin varlığıyla beraber öğrenci sayısı da her geçen sene artmaktadır. Tüm bu koşullara bağlı olarak şehirde yaşayan kişi sayısı her geçen sene artmaktadır. Buna bağlı olarak trafik problemleri meydana gelmiştir. Ayrıca şehir içi ulaşımını sağlayan otobüsler yolcu taleplerini istenilen seviyede karşılayamamaktadır. Uşak ili için tüm bu sorunların tramvay sistemi ile çözülmesi planlanmıştır. Yapılması planlanan tramvay hattının güzergahı Uşak’ta yaşayan insanların yoğun olarak kullandıkları Ankara-İzmir karayolu ile aynı güzergaha sahiptir. Bu güzergah üzerinde dükkanlar, konutlar, devlet dairesi, hastane, üniversite gibi yerler bulunmasından kaynaklı olarak bu karayolu üzerinde şehir içindeki yolculardan kaynaklı trafik de yoğun olarak meydana gelmektedir. Tramvay sistemiyle beraber Uşak için ulaşım kolaylaşacak, yaşanan trafik kazaları ve trafik sorunları minimum seviyeye indirilecek, yolcular istedikleri noktalara daha hızlı, daha güvenli ve daha konforlu bir şekilde varacaktırlar. Ayrıca tramvay sistemiyle beraber çevre ve gürültü kirliliğinin de önüne geçilmiş olacaktır. Sonuç olarak yolcu taleplerinin en iyi şekilde karşılanması tramvay sistemiyle olacaktır.

\section{Sonuçlar ve Tartışma}

Tramvay hattının güzergahı için Uşak ilinin yoğun olarak kullandığı bir güzergah seçilip ve bu güzergah üzerine istasyonlar yerleştirilmiştir. Tramvayın batı hattı üzerinde Uşak Üniversitesi'nin varlığından kaynaklı olarak yapılan hesaplarda günlük 2 yönlü olarak 3500 yolcunun taşınacağı öngörülmüştür. Hesaplanan yolcu sayına göre, Samsun Tramvayı km maliyeti baz alınarak toplam maliyet belirlenmiştir ve 12,76 senede sistemin kendini amorti edeceği hesaplanmıştır.

Sonuç olarak dünya genelin yapılan böyle büyük projelerde sistemin kendisini 15 yıldan kısa bir amorti etmesi projenin uygulanabilirliğinin bir göstergesidir. Uşak Tramvayı Batı Hattının amorti süresi 15 yıldan kısa bir süre olduğu için projenin mali açıdan gerçekleştirilebilirdir. 